\title{
Traumatic Dental Injuries Occurred in Primary Teeth and their Sequel Effects on the Developmental Permanent Successors: A Controlled Study
}

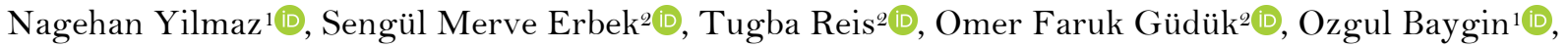 \\ Tamer Tüzüner1(1)
}

'Department of Pediatric Dentistry, Faculty of Dentistry, Karadeniz Technical University, Trabzon, Turkey.

${ }^{2}$ Private Practice, Trabzon, Turkey.

Correspondence: Dr. Nagehan Yilmaz, Karadeniz Technical University, Faculty of Dentistry, Department of Pediatric Dentistry, Trabzon, Turkey. E-mail: nagehany89@yahoo.com

Academic Editor: Alessandro Leite Cavalcanti

Received: 19 May 2021 / Review: 03 July 2021 / Accepted: 16 July 2021

How to cite: Yilmaz N, Erbek SM, Reis T, Güdük OF, Baygin O, Tüzüner T. Traumatic dental injuries occurred in primary teeth and their sequel effects on the developmental permanent successors: a controlled study. Pesqui Bras Odontopediatria Clín Integr. 202 1; $21: \mathrm{e0104.} \mathrm{https://doi.org/10.1590/pboci.2021.153}$

\begin{abstract}
Objective: To examine the types of traumatic dental injuries of the primary teeth (TDI-p) and the longterm sequelae on permanent dentition (LSP) comparing with a control group (CG). In addition, a questionnaire that measures parents' knowledge and awareness was used. Material and Methods: The trauma group (TG) consisted of permanent teeth following TDI-p exposed teeth, while the CG consisted of permanent teeth following unexposed teeth with TDI-p of the same patients. In total, 141 teeth were evaluated in 27 patients. Data concerning such as teeth, when TDI-p occurred, types of treatments and types of LSP were collected. Chi-square test was used for intergroup comparison for gender, type of trauma, LSP, age of trauma and parameters in the parental information questionnaire. Significance level was $\mathrm{p}<0.05$. Results: A statistically significant difference was found in the analysis between TG and CG $(\mathrm{p}<0.001)$. The prevalence of LSP due to TDI-p was $29.6 \%$ and the prevalence of sequelae in CG was $7.4 \%$. The most common LSP was enamel hypoplasia (14.8\%). Parents were aware of the importance of TDI-p, and they had insufficient knowledge about its management. Conclusion: TDI-p can be considered a high-risk factor in the development of LSP. Also, the lack of knowledge in parents should be supported by software-based application systems to be developed.
\end{abstract}

Keywords: Tooth, Deciduous; Tooth Injuries; Tooth Avulsion. 


\section{Introduction}

Dental trauma is an impact injury to teeth and supporting tissues. It usually occurs suddenly, unexpectedly and by chance and often requires urgent intervention [1]. Traumatic dental injuries of the primary teeth (TDI-p) occur at an early age, and most of these injuries are caused by falls at home [2].

Dental damage due to trauma in children can have physical and psychological consequences. It may also result in pain, function loss, emotional stress, adverse effects in developing occlusion, and changes in esthetics [3]. In addition, these injuries may influence further tooth growth, resulting in irreversible damage if they occur during the initial stages of development [4]. One of the most important problems in TDI-p is the possibility of damage to the permanent tooth germ [5]. Many sequelae can be diagnosed before the eruption of the successor permanent tooth using radiographs during follow-up. However, there are also potential the longterm sequelae on permanent dentition (LSP), including hypoplastic defects, root dilacerations, and other enamel or developmental disturbances that are not seen until months or years after the injury when the permanent successors erupt [6,7]. Studies stated that sequelae developed in permanent teeth with a rate of $69 \%$ after intrusive luxation injury, $52 \%$ after total luxation, $34 \%$ after partial luxury, and $27 \%$ after subluxation [8,9]. The most common sequela after TDI-P is enamel hypoplasia and discoloration of enamel $[10]$.

Studies on the LSP after TDI-p are available in the literature and some of them also include a control group [10-12]. Therefore, this study aimed to examine the types of TDI-p and the LSP comparing with control group. In addition, the use of a questionnaire that measures parents' knowledge and awareness about dental injuries makes a difference in the literature.

\section{Material and Methods}

Ethical Clearance

This project has been reviewed and approved by the Ethical Committee Karadeniz Technical University, Faculty of Medicine (2019/104).

\section{Sample Size Calculation}

To calculate the sample size, the risk ratio was found to be 5.39 (95\% confidence interval) in terms of the relation between TDI-p and LSP in the study conducted by Lenzi et al. [10]. The sample size was calculated to estimate with a $25 \%$ deviation (4.04-6.74), and when the sequelae risk was measured at approximately $30 \%$, it was found that it was sufficient to retrospectively include 60 patients in the study. However, as the case group patients can also be considered as the control group, it was determined that 30 patients would be sufficient.

\section{Study Population and Data Collection}

According to the sample size we determined, 94 patients who had trauma during primary dentition registered in our hospital were sought, but communication could be established with only 27 of them. Patients (now aged 6-17) aged between 1-9 with the TDI-p admitted to the Karadeniz Technical University Faculty of Dentistry Department of Pediatric Dentistry Clinic from 2006 to 2014 were selected by assessing the dental records. Patients were included as study subjects based on the following: (i) history of trauma to primary teeth and (ii) the full eruption of their permanent successors and (iii) without any hereditary or systemic disease. Incomplete dental records and radiographic images, affected permanent teeth not fully erupted or with large 
caries lesions, generalize structural defects, restorations or traumatic injuries and patients who had any hereditary or systemic disease were excluded from this study. Trauma records were obtained according to Andreasen and Andreasen classification [13].

The information of patients with TDI-p was obtained from previous dental records and they were called to the hospital for re-examination. The information obtained from previous dental records included; the affected deciduous teeth, the reason for the occurrence, the time and place, the type of trauma, and the treatment applied. During the re-examination, clinical and radiographic examinations were performed on the patients who were included in this study. Permanent teeth with a history of TDI-p, types of sequelae in these teeth, and permanent teeth without a history of TDI-p were recorded. In addition, photographs were taken from the relevant teeth of the patients. Re-examination and photos evaluations were carried out by two independent pre-calibrated pediatric dentists. The trauma group (TG) consisted of erupted permanent teeth that had suffered trauma in their primary teeth, while the control group (CG) consisted of twice as many permanent teeth following the non-traumatized primary teeth on the same patients.

Data collected included; patient's age at the time of trauma, gender, traumatized teeth, type of injury, treatment method and sequelae to permanent successors. More than one tooth could be included from the same patient. In addition, to evaluate the knowledge of the parents of the patient participating in this study about TDI-p a modified questionnaire [14,15] was applied. When the questionnaire was not fully understood by the participants, the researchers were assisted, but the answers were not guided.

\section{Statistical Analysis}

The collected data were imported to Statistical Package for Social Sciences (SPSS) for Windows software, version 16.0 (SPSS Inc., Chicago, IL, USA). The compliance of the data to normal distribution was analyzed using the Shapiro Wilk test. The data not conforming to normal distribution were analyzed by Mann-Whitney U test. Chi-square test was used for intergroup comparison for gender, type of trauma, LSP, age of trauma and parameters in the parental information questionnaire. The statistical significance level was set at $\mathrm{p}<0.05$

\section{Results}

A total of 57 teeth in TG and 114 in CG were evaluated in 27 patients; 12 of these patients were girls $(44.4 \%)$ and 15 of them were boys (55.6\%). Girl patients' age range was between 7-16 years and boy patients' age range was between 9-17 years (patients' ages were between 1-9 years when suffered TDI-p). Out of 27 parents, 21 of them were female and six of them were male. Considering the educational status of the parents; six of them were primary school graduates, three of them were middle school graduates, 10 of them were high school graduates and eight of them were university graduates. While 15 parents stated that they were employed, 12 parents stated that they were unemployed. Two of the parents (7.4\%) had an income below 1500 TL / month, 14 (51.9\%) had an income level of 1500-4000 TL / month and 11 of them (40.7\%) have an income level of more than $4000 \mathrm{TL} / \mathrm{month}$ (Table 1).

Table 1. Sociodemographic distribution of parents.

\begin{tabular}{lcc}
\multicolumn{1}{c}{ Variables } & N & \% \\
\hline Gender & 21 & 77.8 \\
Female & 6 & 22.2 \\
Male & &
\end{tabular}




\begin{tabular}{lcc} 
Patient Education Status & & \\
Primary School & 6 & 22.2 \\
Middle School & 3 & 31.1 \\
High School & 10 & 29.6 \\
University & 8 & \\
Employment Status & & 55.6 \\
Employed & 15 & 44.4 \\
Unemployed & 12 & \\
Income Level & & 7.4 \\
1500 TL altı $>$ & 2 & 51.9 \\
1500-400O TL & 14 & 40.7 \\
4000 TL $<$ & 11 & \\
Patient Gender & & 44.4 \\
Girl & 12 & 55.6 \\
Boy & 15 & \\
\hline
\end{tabular}

Trauma findings were obtained by examining the patients' previous dental records. Trauma affected the anterior dental region in 26 patients $(96.3 \%)$ and the posterior dental region in one patient (3.7\%). It was observed that the teeth most exposed to TDI-p were upper central incisors (26.6\%). Considering the reasons for the occurrence of TDI-p, it was due to falling in 17 patients (63\%), hitting an object in two patients (7.4\%), traffic accidents in one patient (3.7\%), and other causes in one patient (3.7\%). For six patients were not recorded the reason for the occurrence of the trauma. None of the teeth affected by trauma had an injury involving the pulp. Twenty-four patients $(88.9 \%)$ did not have an injury involving dental hard tissue, one patient $(3.7 \%)$ had a root fracture, one patient $(3.7 \%)$ had an alveolar process fracture, and one patient (3.7\%) had another dental hard tissue injury. The most common supporting tissue injury in this study was subluxation (37\%). Three patients (11.1\%) had no supporting tissue injury. Other reported supporting tissue injuries in this study were concussion (7.4\%), subluxation (37\%), extrusion (3.7\%), lateral luxation (3.7\%), intrusion (14.8\%), avulsion (11.1\%) and combined injuries (subluxation + concussion $=3.7 \%$, subluxation + extrusion $=3.7 \%$, subluxation + avulsion $=3.7 \%$, totalizing $11.1 \%)$. In previous trauma records, it was reported that 25 patients $(92.6 \%)$ had no oral mucosa injury, one patient had $(3.7 \%)$ a laceration, and one patient $(3.7 \%)$ had other soft tissue injury. Eighteen patients $(66.7 \%)$ received no treatment, two patients $(7.4 \%)$ received extractions, three patients $(11.1 \%)$ received pulpectomy, one patient $(3.7 \%)$ received restoration, one patient $(3.7 \%)$ received dentures, and one patient (3.7\%) received combined treatment (pulpectomy+ fixation). One patient had missing treatment data (Table 2 ).

Table 2. Supportive tissue trauma frequency and Type of treatment.

\begin{tabular}{lcc}
\multicolumn{1}{c}{ Variables } & N & $\%$ \\
\hline Trauma Type & 3 & 11.1 \\
No Hard Tissue Trauma & 2 & 7.4 \\
Concussion & 10 & 37.0 \\
Subluxation & 1 & 3.7 \\
Extrusion & 1 & 3.7 \\
Lateral Luxation & 4 & 14.8 \\
Intrusion & 3 & 11.1 \\
Avulsion & 3 & 11.1 \\
Combined & 27 & \\
Total & & 66.7 \\
Type of Treatment & 18 & 7.4 \\
Observation & 2 & 11.1 \\
Extraction & 3 &
\end{tabular}




\begin{tabular}{lcc} 
Restorative & 1 & 3.7 \\
Dentures & 1 & 3.7 \\
Combined $^{\mathrm{b}}$ & 1 & 3.7 \\
Unknown & 1 & 3.7 \\
Total & 27 & 100.0 \\
\hline aSubluxation + Concussion $(\mathrm{n}=1 ; 3.7 \%)$. Subluxation + Extrusion $(\mathrm{n}=1 ; 3.7 \%) ;$ Subluxation
\end{tabular}

+ Avulsion $(\mathrm{n}=1 ; 3.7 \%)$; ${ }^{\text {PPulpectomy }+ \text { Fixation. }}$

Two pediatric dentists examined successive permanent teeth clinically and radiographically. The interobserver reliability value (Cohen-Kappa) was 0.743. A statistically significant difference was found in the analysis between TG and CG ( $p<0.001)$. The prevalence of LSP due to TDI-p was 29.6\% ( $\mathrm{n}=8)$ in TG and the prevalence of sequelae in CG was $7.4 \%(n=2)$. Thus, the prevalence of LSP in TG group was 4 times higher than CG group. The long-term sequelae on permanent dentition according to the type of trauma are as follows: lateral agglutination/root dilaceration in a patient without a supportive tissue trauma, enamel hypoplasia in a patient with a concussion, enamel hypoplasia in a patient with a subluxation, enamel hypoplasia in a patient with lateral luxation, crown dilaceration in a patient with avulsion, root dilaceration in another patient with an intrusion, enamel hypoplasia in a patient with a combined trauma (subluxation + extrusion) and combined sequela (discoloration of enamel + enamel hypoplasia) in a patient with a combined trauma (subluxation + avulsion). In this study, the largest number of LSP was observed following the intrusion and combined trauma $(7.4 \%, \mathrm{n}=2$, for each). The most common LSP was enamel hypoplasia $(14.8 \%, \mathrm{n}=4)$. No sequelae were found in the teeth following the extrusion. In the control group, there was a patient with enamel discoloration and a patient with combined defects (discoloration of enamel and enamel hypoplasia), not due to the primary teeth trauma (Tables 3 and 4 ).

Table 3. Prevalence type of sequelae in permanent successors according to different traumatic dental injuries in primary teeth (TDI-p).

\begin{tabular}{|c|c|c|c|c|c|c|c|}
\hline TG*/CG & $\begin{array}{c}\text { No } \\
\text { Sequelae } \\
\mathrm{N}\end{array}$ & $\begin{array}{c}\text { Discoloration } \\
\text { of Enamel } \\
\mathrm{N}\end{array}$ & $\begin{array}{c}\text { Crown } \\
\text { Dilaceration } \\
\mathrm{N}\end{array}$ & $\begin{array}{c}\text { Enamel } \\
\text { Hypoplasia } \\
\mathrm{N}\end{array}$ & $\begin{array}{c}\text { Root } \\
\text { Dilacerations } \\
\mathrm{N}\end{array}$ & $\begin{array}{c}\text { Lateral Agg. } \\
\text { /Root Dil.\# } \\
\text { N }\end{array}$ & Combined $^{\mathrm{d}}$ \\
\hline No Hard Tissue Trauma & $2 / 2$ & $\mathrm{O} / \mathrm{1}$ & $\mathrm{O} / \mathrm{O}$ & $\mathrm{O} / \mathrm{O}$ & $\mathrm{O} / \mathrm{O}$ & $1 / 0$ & $\mathrm{O} / \mathrm{O}$ \\
\hline Concussion & $1 / 2$ & $\mathrm{O} / \mathrm{O}$ & $\mathrm{O} / \mathrm{O}$ & $1 / 0$ & $\mathrm{O} / \mathrm{O}$ & $\mathrm{O} / \mathrm{O}$ & $\mathrm{O} / \mathrm{O}$ \\
\hline Subluxation & $9 / 10$ & $\mathrm{O} / \mathrm{O}$ & $\mathrm{O} / \mathrm{O}$ & $1 / 0$ & $\mathrm{O} / \mathrm{O}$ & $\mathrm{O} / \mathrm{O}$ & $\mathrm{O} / \mathrm{O}$ \\
\hline Extrusion & $1 / 1$ & $\mathrm{O} / \mathrm{O}$ & $\mathrm{O} / \mathrm{O}$ & $\mathrm{O} / \mathrm{O}$ & $\mathrm{O} / \mathrm{O}$ & $\mathrm{O} / \mathrm{O}$ & $\mathrm{O} / \mathrm{O}$ \\
\hline Lateral Luxation & $0 / 1$ & $\mathrm{O} / \mathrm{O}$ & $\mathrm{O} / \mathrm{O}$ & $1 / 0$ & $\mathrm{O} / \mathrm{O}$ & $\mathrm{O} / \mathrm{O}$ & $\mathrm{O} / \mathrm{O}$ \\
\hline Intrusion & $3 / 4$ & $\mathrm{O} / \mathrm{O}$ & $\mathrm{O} / \mathrm{O}$ & $\mathrm{O} / \mathrm{O}$ & $1 / 0$ & $\mathrm{O} / \mathrm{O}$ & $\mathrm{O} / \mathrm{O}$ \\
\hline Avulsion & $2 / 3$ & $\mathrm{O} / \mathrm{O}$ & $1 / 0$ & $\mathrm{O} / \mathrm{O}$ & $\mathrm{O} / \mathrm{O}$ & $\mathrm{O} / \mathrm{O}$ & $\mathrm{O} / \mathrm{O}$ \\
\hline Combined & $1^{\mathrm{a} / 2}$ & $\mathrm{O} / \mathrm{O}$ & $\mathrm{O} / \mathrm{O}$ & $1^{\mathrm{b}} / \mathrm{O}$ & $\mathrm{o} / \mathrm{O}$ & $\mathrm{O} / \mathrm{O}$ & $1^{\mathrm{c} / 1}$ \\
\hline Total & $19 / 25$ & $\mathrm{O} / \mathrm{1}$ & $1 / 0$ & $4 / 0$ & $1 / 0$ & $1 / 0$ & $1 / 1$ \\
\hline Trauma Group*** & \multicolumn{6}{|c|}{$29.6 \%(\mathrm{~N}=8)$} & $\mathrm{p}<0.001^{* * *}$ \\
\hline Control Group & \multicolumn{6}{|c|}{$7.4 \%(\mathrm{~N}=2)$} & \\
\hline
\end{tabular}

\#Lateral Agglutination/Root Dilaceration; *Chi-Square test; **Successor Permanent Teeth; ***Association of the frequency of sequelae between the successor permanent teeth and the control group; ${ }^{a}$ Subluxation + Concussion; ${ }^{b}$ Subluxation + Extrusion; ${ }^{c}$ Subluxation + Avulsion; ${ }^{\mathrm{d} D i s c o l o r a t i o n}$ of Enamel + Enamel Hypoplasia.

Table 4. Prevalence of type of sequelae in permanent successors according to different age groups.

\begin{tabular}{|c|c|c|c|c|c|c|c|c|c|c|c|}
\hline \multirow{3}{*}{$\begin{array}{l}\text { Types of Sequelae in } \\
\text { Permanent Dentition }\end{array}$} & \multicolumn{2}{|c|}{ Groups } & \multicolumn{9}{|c|}{ Age (years) at Time of Trauma in Trauma Group } \\
\hline & TG & $\mathrm{CG}$ & $\mathrm{N}(\%)$ & $\mathrm{N}(\%)$ & $\mathrm{N}(\%)$ & $\mathrm{N}(\%)$ & $\mathrm{N}(\%)$ & $\mathrm{N}(\%)$ & $\mathrm{N}(\%)$ & $\mathrm{N}(\%)$ & $\mathrm{N}(\%)$ \\
\hline & $\mathrm{N}(\%)$ & $\mathrm{N}(\%)$ & 1 & 2 & 3 & 4 & 5 & 6 & 7 & 8 & 9 \\
\hline No Sequelae & $19(70.4)$ & $25(92.6)$ & $1(3.7)$ & $3(11.1)$ & $4(14.8)$ & $2(7.4)$ & $2(7.4)$ & $1(3.7)$ & $1(3.7)$ & $1(3.7)$ & $4(14.8)$ \\
\hline Discoloration of Enamel & $\mathrm{O}$ & $1(3.7)$ & - & - & - & - & - & - & - & - & - \\
\hline Enamel Hypoplasia & $4(14.8)$ & o & - & - & $3(11.1)$ & - & $1(3.7)$ & - & - & - & - \\
\hline Crown Dilaceration & $1(3.7)$ & $\mathrm{O}$ & - & - & - & - & - & - & - & - & $1(3.7)$ \\
\hline
\end{tabular}




\begin{tabular}{|c|c|c|c|c|c|c|c|c|c|c|c|}
\hline Root Dilacerations & $1(3.7)$ & 0 & - & - & - & - & - & $1(3.7)$ & - & - & - \\
\hline Lateral Ag./Root Dil. & $1(3.7)$ & $\mathrm{O}$ & - & - & - & $1(3.7)$ & - & - & - & - & - \\
\hline Combined $^{a}$ & $1(3.7)$ & $1(3.7)$ & - & - & - & - & $1(3.7)$ & - & - & - & - \\
\hline Total & 27 & 27 & $1(3.7)$ & $3(11.1)$ & $7(25.9)$ & $3(11.1)$ & $4(14.8)$ & $2(7.4)$ & $1(3.7)$ & $1(3.7)$ & $5(18.5)$ \\
\hline
\end{tabular}

*Chi-Square test; $\mathrm{p}=0.544=$ Association with presence of sequelae in permanent successors with age for the traumatic dental injuries in

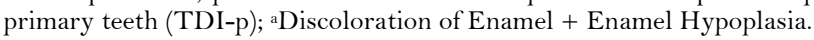

Parents of the patients were asked to take a four-question survey. Twenty-one of the parents (77.8\%) marked the "Correct" option in question 1, while six of the parents (22.2\%) marked the "False" option. In the second question, 16 of the parents (59.3\%) chose the "Correct" option, and 11 of them chose the "False" option. In the 3 rd question, it was seen that $20(74.1 \%)$ of the parents ticked the "Correct" option, and seven (25.9\%) of them ticked the "False" option. Finally, in the 4th question, six of the parents $(22.2 \%)$ stated that they wanted to get information from television, while the other 21 parents $(77.8 \%)$ stated that they wanted to get information via mobile applications (Figure 1).

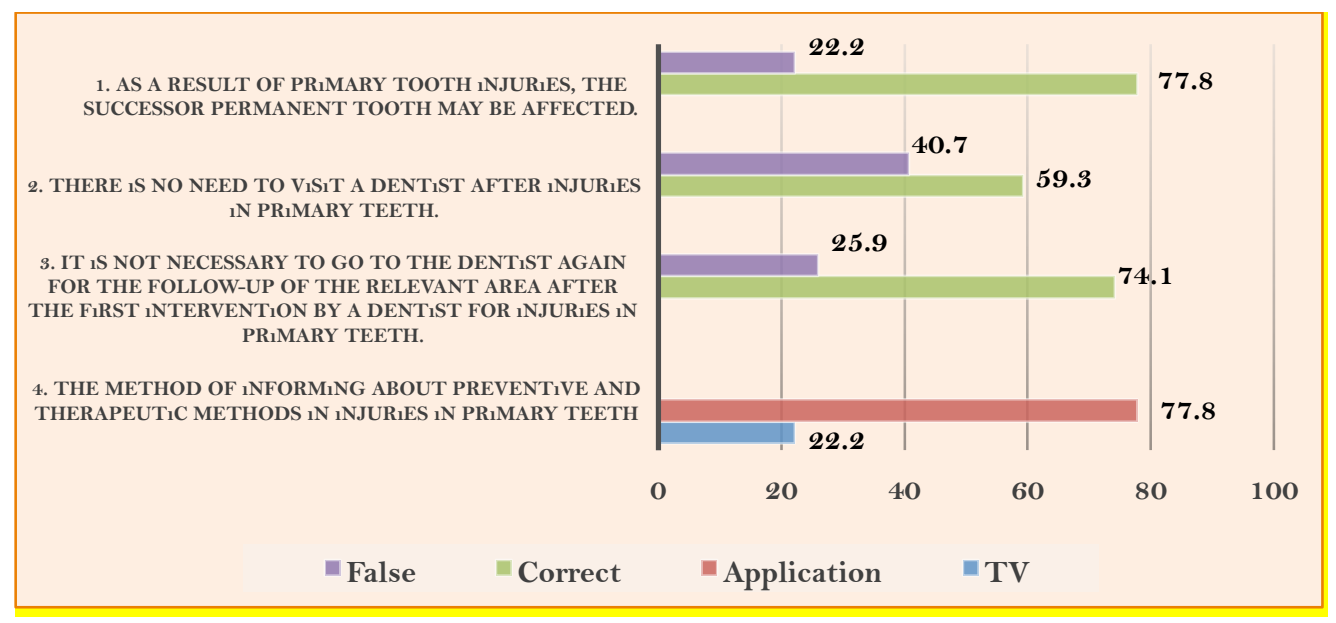

Figure 1. Parental responses regarding dental trauma.

\section{Discussion}

TDI-p is common among dental traumas and sometimes may require urgent intervention. However, LSP creates effects that may affect the quality of life of the child in the future. Therefore, it becomes important to understand the related concepts of TDI-p and LSP [10,16].

The hypothesis of the study was accepted. Sequelae detected in permanent teeth in the case group created a statistically significant difference compared to the control group $(\mathrm{p}<0.001)$. The prevalence of LSP due to TDI-p was $29.6 \%$ and it was compared to the development disturbances in the CG, which was $7.4 \%$. Lenzi et al. [10] reported similar rates of 7\% in CG group and 28.9\% in TG group. Also, in literature prevalence of LSP following TDI-p has been reported to range between 20.2\% and 41.3\% [10,17]. A similar result was reported by Andreasen and Ravn [8], and in both studies [8,10], similar to this study, the CG was composed by contralateral successors of non-traumatized primary teeth.

Differently, Scerri et al. [18] reported that a significant difference between TG $(52 \%)$ and CG (10\%) in terms of LSP after TDI-p. Also, Andreasen and Ravn [9] reported a difference of only 13\% more sequelae in the TG. This difference may be related to the parents' inaccurate memory, especially for CG teeth, as the authors have noted that the same patients in CG were not used in the relevant studies [1-3]. As Lenzi et al. [10] stated LSP can be confused with disorders such as molar-incisor hypomineralization, amelogenesis 
imperfecta and fluorosis, in order to obtain a more objective result, the control group in the study was selected from the same patients.

In this study, $88.9 \%$ of the injuries did not involve hard tissue. Minor traumas, such as enamel fractures, and uncomplicated enamel-dentin fractures, are usually overlooked by parents [18]. This might explain the low percentage of hard tissue injuries reported in this study group. In this study, subluxation $(37 \%)$, intrusive luxation (14.8\%), avulsion (11.1\%) and combined injuries (subluxation + concussion $=3.7 \%$, subluxation + extrusion $=3.7 \%$, subluxation + avulsion $=3.7 \%$, totalizing $11.1 \%$ ) were reported with the highest number. However, LSP types were followed by more combined injuries (subluxation + concussion, subluxation + extrusion, subluxation + avulsion $=25 \%)$. Similarly, Andreasen et al. [8] stated that a minor impact only disturbs the thin soft tissue or the hard tissue barrier between the primary tooth and its permanent successor. This might explain the low percentage of LSP after injuries such as concussion and subluxation (12.5\%, for each one). However, enamel defects that occur even after concussion and subluxation may suggest that sequelae may occur after all TDI-p types, as reported by other authors [10,19].

In contrast to the result of this study, a high prevalence of LSP after the intrusion was reported in the literature [10,11,20-22]. This situation might be explained by an alveolar socket fracture or crush that increases the risk of a direct transfer of the injury to the developing permanent tooth germ. Also, types of LSP as crown dilaceration, odontoma-like malformation, sequestration of the tooth germ, and hypoplasia are expected to occur after intrusion [10,20]. In this study, root dilaceration (3.7\%) was found similarly after intrusion in the TG group. Some authors [12,22] stated that they observed LSP after extrusion luxation and avulsion injuries. Although, in this study, crown dilaceration was observed after avulsion injuries but was not after extrusion luxation. Analyzed a small number of patients can be considered the reason both lower prevalence of LSP after intrusion and not observed LSP after extrusion luxation.

Tewari et al. [22] indicated that mild LSP was observed more than severe sequelae. Also, in this study, enamel hypoplasia that mild LSP was the most common sequelae in TG group and enamel discoloration was the most common sequelae in CG group. Similarly, Lenzi et al. [10] reported that enamel hypoplasia was the most common after TDI-p; enamel defects were mostly found in the CG. Therefore, it can be explained, enamel discoloration could have occurred in the adjacent teeth that might be affected indirectly due to the hemorrhages of the traumatized tooth [12].

In this study, the relationship between the age of injury and the type/presence of sequelae was not found to be statistically significant $(\mathrm{p}=0.544$ and $\mathrm{p}=0.804)$, contrary to the literature $[10,18]$. It might be attributed to the relatively low sample size in the study. As similarly, De Amorim et al. [11] found no significant association between type of TDI-p and LSP, as reported by Jácomo and Campos [23]. However, although it is not statistically significant, in this study, it was found that $11.1 \%$ of enamel hypoplasia occurred due to trauma at the age of 3 years. Although the other sequelae found were equal and $3.7 \%$, they occurred after traumas at the age of 4 years and over. The fact that most of the TDI-p in the study occurred at the age of 4 and above may explain the low number of sequelae. Supporting this study, Lenzi et al. [10] stated that a low number of sequelae may occur due to traumas at the age of 5 years and over. However, they reported that the development of permanent tooth germ in traumas occurring at the age of 2 years is in the early stages, so there will be more sequels after TDI-p [10]. The reason for this is that the germs of incisors are particularly sensitive to traumas that occur between the ages of 4 months and 4 years, which are the early stages of their development [20,21]. 
In this study, $66.7 \%$ of the TDI-P were followed up, $11.1 \%$ pulpectomy, $7.4 \%$ extraction and $3.7 \%$ restoration, appliance and combined treatment (pulpectomy + fixation) was applied. The reason for this situation may be the high rate of subluxation (37\%) and the absence of dental hard tissue injuries in $88.9 \%$ of the cases. This may mean that preventive treatments are preferred for primary tooth injuries. De Amorim et al. [11] support this situation with the low rate of extraction in deciduous tooth injuries and the high rate of preventive treatments. Follow-up may have been made for subluxation incidence in accordance with the trauma treatment guidelines [24]. In addition, it has been stated that aggressive treatments may prevent the regular formation of dental tissues, so regular follow-up after correct diagnosis will reduce the cost of treatment and the possibility of sequelae will be minimized [11,17].

A total of $77.8 \%$ of the parents were female and $22.2 \%$ were male. It was determined that $37 \%$ of the parents were college graduates, $29.6 \%$ were university graduates and $44.4 \%$ were unemployed. Similarly, in another study, a high level of education was found [25,26]. The fact that most of the parents involved are women and the unemployment rate may mean that most mothers are always available at home and ready to provide first aid if an unfortunate incident of dental trauma occurs, as Al-Sehabiany et al. [25] found in their study.

In the questionnaire questions used in the study, rather than a comprehensive information scan like other studies [25,27], questions aimed at evaluating the general knowledge level of the parents about the importance, treatment and follow-up of TDI-p were used. In the questionnaire questions, it was observed that the parents had correct information about the effect on permanent tooth germs after TDI-p (77.8\%), while they had low information about the necessity of going to the dentist (40.7\%) and establishing follow-up appointments $(25.9 \%)$ after TDI-p. This situation does not coincide with the results of mothers who are aware of immediate treatment after TDI-p reported by Al-Sehabiany et al. [25]. However, other studies [27,28] concluded that, similar to this study, parents should be made aware of TDI-p. Additionally, Al-Sehabiany et al. [25] reported that more than $83 \%$ of the mothers wanted to receive further information about TDIs, which is encouraging. In this study, it can be concluded that parents who have children with a history of trauma need training on TDI-p management and follow-up due to their incomplete information. It can be thought that it would be effective to have this training from the application as parents prefer with $77.8 \%$ in the survey.

Failure to perform a tooth-based analysis due to incomplete processed data based on previously obtained dental records, also insufficient / wrong memory of parents were limitations of this study.

\section{Conclusion}

The sequelae on permanent dentition formation rate after TDI-p was found 4 times higher than control group. After TDI-p, the highest LSP rate was observed in combined traumas (subluxation + concussion, subluxation + extrusion, subluxation + avulsion). The most common LSP was found as enamel hypoplasia.

\section{Authors' Contributions}

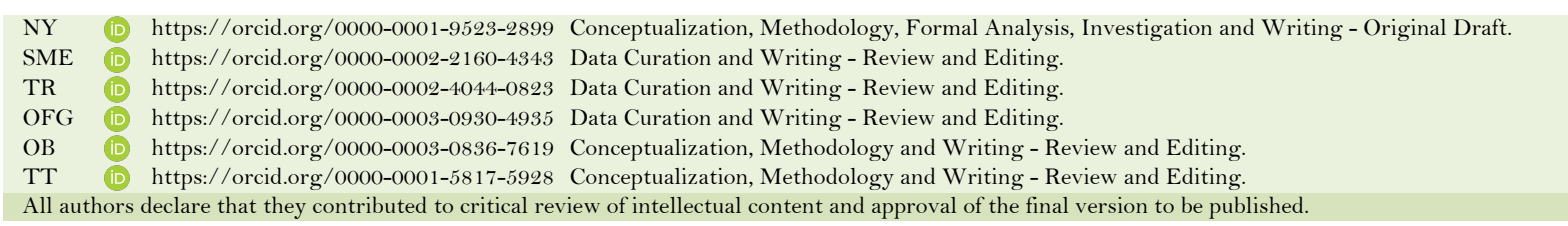




\section{Financial Support}

None.

\section{Conflict of Interest}

The authors declare no conflicts of interest.

\section{Data Availability}

The data used to support the findings of this study can be made available upon request to the corresponding author.

\section{References}

[1] Lam R. Epidemiology and outcomes of traumatic dental injuries: a review of the literature. Aust Dent J 2016; 61(Suppl 1):4-20. https://doi.org/10.1111/adj.12395

[2] Bastone EB, Freer TJ, McNamara JR. Epidemiology of dental trauma: a review of the literature. Aust Dent J 2000; 45(1):2-9. https://doi.org/10.1111/j.1834-7819.2000.tbo0234.x

[3] Gomes MC, Pinto-Sarmento TC, Costa EM. Impact of oral health conditions on the quality of life of preschool children and their families: a cross-sectional study. Health Qual Life Outcomes 2014; 12:55. https://doi.org/10.1186/1477-7525-12-55

[4] Bani M, Bodur H, Kapci EG. Are behaviour risk factors for traumatic dental injuries in childhood different between males and females? Eur J Paediatr Dent 2015; 16(1):29-32.

[5] Santo Jácomo DRE, Campos V. Prevalence of sequelae in the permanent anterior teeth after trauma in their predecessors: a longitudinal study of 8 years. Dent Traumatol 2009; 25(3):300-4. https://doi.org/10.1111/j.1600-9657.2009.00764.x

[6] Andreasen JO, Sundström B, Ravn JJ. The effect of traumatic injuries to primary teeth on their permanent successors. I. A clinical and histologic study of 117 injured permanent teeth. Scand J Dent Res 1971; 79(4):219-83. https://doi.org/10.1111/j.1600-0722.1971.tbo2013.x

[7] Lenzi MM, Alexandria AK, Ferreira DM. Does trauma in the primary dentition cause sequelae in permanent successors? A systematic review. Dent Traumatol 2015; 31(2):79-88. https://doi.org/10.1111/edt.12149

[8] Andreasen JO, Ravn JJ. The effect of traumatic injuries to primary teeth on their permanent successors. II. A clinical and radiographic follow-up study of 213 teeth. Eur J Oral Sci 1971; 79(4):284-94. https://doi.org/10.1111/j.1600-0722.1971.tb02014.x

[9] Andreasen JO, Ravn JJ. Enamel changes in permanent teeth after trauma to their primary predecessors. Eur J Oral Sci 1973; 81(3):203-9. https://doi.org/10.1111/j.1600-0722.1973.tbo0330.x

[10] Lenzi MM, da Silva Fidalgo TK, Luiz RR. Trauma in primary teeth and its effect on the development of permanent successors: a controlled study. Acta Odontol Scand 2019; 77(1):76-81. https://doi.org/10.1080/00016357.2018.1508741

[11] de Amorim Lde F, Estrela C, da Costa LR. Effects of traumatic dental injuries to primary teeth on permanent teeth a clinical follow-up study. Dent Traumatol 2011; 27(2):117-21. https://doi.org/10.1111/j.1600-9657.2010.00959.x

[12] von Arx T. Developmental disturbances of permanent teeth following trauma to the primary dentition. Aust Dent J 1993; 38(1):1-10. https://doi.org/10.1111/j.1834-7819.1993.tb05444.x

[13] Andreasen JO, Andreasen FM. Textbook and Color Atlas of Traumatic Injuries to the Teeth. $4^{\text {th }}$. ed. Copenhagen: Mosby; 2010.

[14] Alsadhan SA, Alsayari NF, Abuabat MF. Teachers' knowledge concerning dental trauma and its management in primary schools in Riyadh, Saudi Arabia. Int Dent J 2018; 68(5):306-13. https://doi.org/10.1111/idj.12385

[15] Nirwan M, Syed AA, Chaturvedi S. Awareness in primary school teachers regarding traumatic dental injuries in children and their emergency management: A survey in South Jaipur. Int J Clin Pediatr Dent 2016; 9(1):62-6. https://doi.org/10.5005/jp-journals-10005-1335

[16] Souza JG, Martins AM, Silveira MF. Impact of oral clinical problems on oral health-related quality of life in Brazilian children: a hierarchical approach. Int J Paediatr Dent 2017; 27(1):66-78. https://doi.org/10.1111/ipd.12229

[17] Da Silva Assunção LR, Ferelle A, Iwakura ML. Effects on permanent teeth after luxation injuries to the primary predecessors: a study in children assisted at an emergency service. Dent Traumatol 2009; 25(2):165-70. https://doi.org/10.1111/j.1600-9657.2008.00759.x

[18] Scerri E, Gatt G, Camilleri S. Morphologic and developmental disturbances of permanent teeth following trauma to primary dentition in a selected group of Maltese children. Quintessence Int 2010; 41(9):717-24.

[19] Skaare AB, Aas AL, Wang NJ. Enamel defects on permanent successors following luxation injuries to primary teeth and carers' experiences. Int J Paediatr Dent 2015; 25(3):22 1-28. https://doi.org/10.1111/ipd.12136

[20] Sennhenn-Kirchner S, Jacobs HG. Traumatic injuries to the primary dentition and effects on the permanent successors a clinical follow-up study. Dent Traumatol 2006; 22(5):237-41. 
https://doi.org/10.1111/j.1600-9657.2006.00383.x

[21] Bardellini E, Amadori F, Pasini S. Dental anomalies in permanent teeth after trauma in primary dentition. J Clin Pediatr Dent 2017; 41(1):5-9. https://doi.org/10.17796/1053-4628-41.1.5

[22] Tewari N, Mathur VP, Singh N. Long-term effects of traumatic dental injuries of primary dentition on permanent successors: a retrospective study of 596 teeth. Dent Traumatol 2018; 34(2):129-34. https://doi.org/10.1111/edt.12391

[23] Jácomo DRES, Campos V. Prevalence of sequelae in the permanent anterior teeth after trauma in the predecessors - a longitudinal study of 8 years. Dent Traumatol 2009; 25(3):300-4. https://doi.org/10.1111/j.1600-9657.2009.00764.x

[24] Day PF, Flores MT, O'Connell AC. International Association of Dental Traumatology guidelines for the management of traumatic dental injuries: 3. Injuries in the primary dentition. Dent Traumatol 2020; 36(4):343-59. https://doi.org/10.1111/edt.12576

[25] Al-Sehaibany FS, Alajlan R, Almubarak D. Knowledge on management of traumatic dental injuries among Saudi mothers. Clin Cosmet Investig Dent 2018; 10:123-8. https://doi.org/10.2147/CCIDE.S167152

[26] Hegde A, Pradeep Kumar K. Knowledge of dental trauma among mothers in Mangalore. Dent Traumatol 2010; 26(5):417-21. https://doi.org/10.1111/j.1600-9657.2010.00905.x

[27] Vergotine RJ, Koerber A. The relationship of dental visits to parental knowledge of management of dental trauma. Pediatr Dent 2010; 32(4):329-32.

[28] Nikam AP, Kathariya MD, Chopra K. Knowledge and attitude of parents/caretakers toward management of avulsed tooth in Maharashtrian Population: a questionnaire method. J Int Oral Health 2014; 6(5):1-4. 